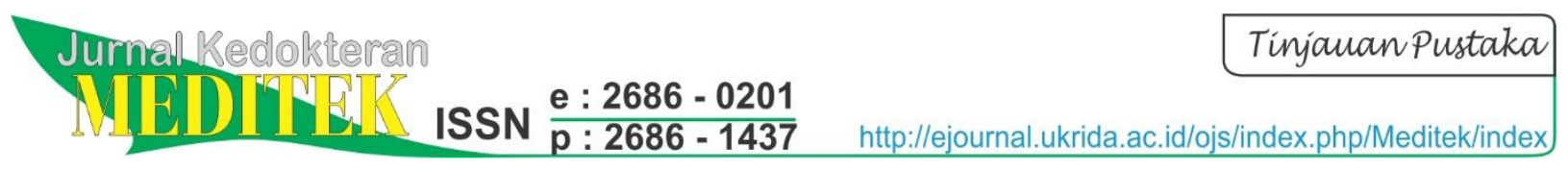

\title{
Diare Akut pada Anak yang Disebabkan oleh Infeksi
}

\author{
Arvin Leonard Sumadi Jap ${ }^{1}$, Ariani Dewi Widodo²
}

\author{
${ }^{1}$ RSAB Harapan Kita, Jakarta, Indonesia \\ ${ }^{2}$ SMF Ilmu Kesehatan Anak, RSAB Harapan Kita, Jakarta, Indonesia \\ Alamat Korespondensi: vinz_jap@ hotmail.com
}

\begin{abstract}
Abstrak
Diare masih menjadi penyebab utama morbiditas dan mortalitas pada anak di negara berkembang. Etiologi diare pada anak didominasi oleh patogen enterik seperti virus, bakteri, dan parasit. Organisme patogen enterik yang cukup sering menjadi penyebab diare adalah rotavirus, E.coli, Shigella spp., Salmonella spp., Vibrio cholerae, dan Entamoeba histolytica. Selama beberapa dekade terakhir, pengetahuan mengenai patogenesis diare akut yang disebabkan oleh infeksi mengalami perkembangan. Tiap organisme menyebabkan gejala diare yang berbeda. Dengan mengetahui gejala dan etiopatogenesis diare akut yang disebabkan oleh infeksi secara tepat, pemberian antibiotik secara berlebihan dapat dicegah sehingga akan mengurangi angka resistensi antibiotik. Tujuan tinjauan pustaka ini adalah untuk memberikan pengetahuan mengenai etiopatogenesis dan tata laksana diare akut yang disebabkan oleh infeksi. Perbaikan hygiene dan sanitasi lingkungan penting untuk mencegah diare akut pada anak. Pemberian cairan rehidrasi oral dengan osmolaritas rendah efektif dalam mengurangi durasi dan frekuensi diare akut dengan dehidrasi ringan-sedang dan mengurangi tingkat kematian yang disebabkan oleh diare akut.
\end{abstract}

Kata Kunci: bakteri, diare, parasit, rehidrasi, virus

\section{Acute Diarrhea Caused by Infection in Children}

\begin{abstract}
Diarrhea is a leading cause of childhood morbidity and mortality in developing countries. The etiology of diarrhea in children is dominated by infectious enteric pathogens such as viruses, bacteria, and parasites. Enteric pathogenic organisms that often cause diarrhea are rotavirus, E. coli, Shigella spp., Salmonella spp., Vibrio cholerae, Entamoeba histolytica. For the last few decades, knowledge about the pathogenesis of acute diarrhea caused by infection has developed. Each organism causes different diarrhea symptoms. Knowing the symptoms and etiopathogenesis of acute diarrhea, prevents overuse administration of antibiotics so it can decrease rates of antibiotic-resistant. The aim of the present comprehensive review was to provide current state of knowledge about etiopathogenesis and management of acute diarrhea caused by infection. Improvement in hygiene and environment sanitation is important to prevent acute diarrhea in children. Oral rehidration with low osmolarity is effective to decrease duration and frequency of acute diarrhea with mildmoderate dehydration and lessen mortality caused by acute diarrhea.
\end{abstract}

Keywords: bacteria, diarrhea, parasite, virus, oral rehydration solution 


\section{Pendahuluan}

Menurut World Health Organization (WHO), diare merupakan penyebab utama morbiditas dan mortalitas pada anak terutama di negara berkembang, dan merupakan faktor risiko terjadinya malnutrisi. ${ }^{1}$ Sekitar 12 juta anak di negara berkembang meninggal sebelum usia 5 tahun, dan $70 \%$ kematian disebabkan oleh lima masalah kesehatan termasuk diare. ${ }^{2}$ Penyebab diare pada anak saat ini didominasi oleh patogen enterik seperti virus, bakteri, dan parasit.

Pada pemeriksaan feses anak dengan diare akut di rumah sakit ditemukan bahwa pada $75 \%$ anak terdapat organisme patogen enterik. ${ }^{3}$ Saat ini rotavirus dan E. coli merupakan organisme penyebab tersering diare akut di negara berkembang, walaupun di Eropa dan Amerika infeksi rotavirus sudah mulai digeser oleh norovirus karena adanya vaksin rotavirus ${ }^{2,3}$ Organisme patogen enterik lain yang cukup sering menyebabkan diare adalah Salmonella spp (nontifoid), Shigella spp, Vibrio cholerae, Campylobacter ss, dan Cryptosporidium spp.$^{1,2}$

Selain infeksi, diare akut bisa disebabkan oleh alergi, intoleransi, malabsobrsi, dan intoksikasi. Artikel ini berfokus pada diare akut yang disebabkan oleh infeksi karena menjadi penyebab tersering diare akut pada anak terutama di Indonesia yang merupakan negara berkembang.

\section{Definisi Diare Akut}

Diare atau sering disebut gastroenteritis akut adalah buang air besar dengan konsistensi yang lebih lunak atau cair yang terjadi dengan frekuensi $\geq 3 \mathrm{x}$ dalam waktu 24 jam. ${ }^{1,3}$ Hal yang perlu diperhatikan adalah frekuensi defekasi, konsistensi feses, dan jumlah feses. Jika konsistensi feses tidak lebih lunak atau cair namun sering bukanlah diare. ${ }^{1,3}$ Bayi yang diberikan ASI sering buang air besar dengan konsistensi lunak dan hal ini juga bukanlah diare. ${ }^{1}$

\section{Patogen Spesifik}

\section{Diare Akut karena Virus}

Virus merupakan patogen tersering penyebab diare akut pada anak dengan prevalensi tertinggi pada usia antara 3 sampai 24 bulan. Hal ini disebabkan oleh sistem pertahanan tubuh anak usia 3 hingga 24 bulan masih belum cukup matang. Penyebab tersering diare yang disebabkan oleh virus adalah grup dari rotavirus. ${ }^{4}$

Rotavirus merupakan penyebab $15-25 \%$ diare pada anak usia 6-24 bulan terutama pada negara berkembang karena buruknya sanitasi dan kepadatan penduduk. ${ }^{1,5}$ Berdasarkan spesifisitas antigen dan protein kapsid VP6, ditemukan tujuh grup berbeda rotavirus (A-G) dan hanya grup A, B, dan $\mathrm{C}$ yang menyebabkan diare pada anak. Rotavirus grup A adalah penyebab utama diare berat pada anak di bawah usia 5 tahun. ${ }^{4}$

Rotavirus menghasilkan enterotoksin yang akan merusak epitel dari usus halus, sehingga vilivili menjadi rusak. Hal ini menyebabkan pengurangan aktivitas dari laktase dan disakaridase lainnya yang menyebabkan absorbsi karbohidrat terganggu. ${ }^{1,45}$ Transmisi terjadi secara fekal-oral atau kemungkinan bisa dari airborne droplet. ${ }^{1,5}$ Rotavirus menyebabkan diare cair dengan muntah yang disertai rasa tidak nyaman pada perut, demam, dan dehidrasi. ${ }^{1,4,5}$

Setelah ditemukan vaksin rotavirus, kasus diare yang disebabkan oleh rotavirus menurun drastis. 3,4

\section{Diare Akut karena Bakteri}

Walaupun lebih jarang menyebabkan diare dibandingkan virus, infeksi bakteri tetap merupakan penyebab penting diare akut pada anak. Gejala yang biasa timbul adalah demam tinggi (lebih dari $40^{\circ} \mathrm{C}$ ), diare berdarah, dan nyeri perut hebat. Gejala muntah dan respirasi lebih sering muncul pada diare akut viral daripada bakterial. ${ }^{5}$

\subsection{Escherichia coli}

Bakteri E.coli merupakan flora normal yang terdapat dalam tubuh manusia dan berperan sebagai mikrobiota usus. ${ }^{1,6}$ Hanya beberapa jenis E.coli yang menyebabkan diare. ${ }^{6}$ Sampai saat ini ditemukan 5 grup $E$. coli yang menyebabkan diare yaitu enterotoxigenic E. coli (ETEC), enterohaemorrhagic (shiga-toxin-producing) E. coli (EHEC/STEC), enteroaggregative E. coli (EAEC), enteropathogenic E. coli (EPEC), dan enteroinvasive E. coli (EIEC) ${ }^{6-8}$ Transmisi bakteri ini melalui makanan dan minuman yang terkontaminasi. ${ }^{1,7}$

Antibiotik bukan tata laksana lini pertama pada diare yang disebabkan oleh E.coli. Antibiotik hanya diberikan pada diare berat yang disebabkan oleh E.coli. Antibiotik yang dapat diberikan adalah azithromisin, cefixime, atau trimetroprim dan sulfametoksazol. Untuk anak yang dicurigai terinfeksi EHEC, tidak dianjurkan diberikan antibiotik, karena dapat meningkatkan risiko terjadinya sindrom hemolitik uremik. ${ }^{3}$

Enteropathogenic E. coli (EPEC) merupakan strain pertama yang berhasil diidentifikasi sebagai 
penyebab diare patogenik pada bayi dan anak-anak di beberapa negara bagian Eropa. Kelainan histopatologis oleh EPEC dikenal sebagai lesi attaching dan effacing (A/E), disebabkan oleh bakteri yang melekat secara kuat pada epitel usus dan rusaknya mikrovili enterosit. Protein intimin membantu proses pelekatan bakteri pada bagian luar membran sel dan protein ini dikode oleh gen eae. Gen eae saat ini digunakan dalam diagnosis molekular EPEC. 6,7

Enterotoxigenic E. coli (ETEC) adalah penyebab utama diare akut pada anak di negara berkembang. Dua faktor virulen penting pada ETEC adalah faktor kolonisasi dan enterotoksin. ${ }^{1}$ Bakteri ETEC melekat pada epitel usus dengan bantuan struktur protein pada permukaannya yang dikenal sebagai faktor kolonisasi. Setelah melekat dan melakukan kolonisasi, ETEC menghasilkan enterotoksin heat-labile (LT) dan/atau heat-stable (ST). Toksin ini mengganggu membran kanal ion dengan meningkatkan cAMP intrasel, menyebabkan hilangnya ion dan sejumlah cairan, dan menyebabkan karakteristik diare yang cair. ${ }^{6,7}$ ETEC tidak merusak dan menginvasi mukosa usus. ETEC menjadi penyebab utama traveler's diarrhea. ${ }^{1,9}$ Diare ini sembuh dengan sendirinya tanpa pengobatan. ${ }^{1}$

Enterohaemorrhagic (shiga-toxin-producing) E. coli (EHEC/STEC) banyak ditemukan di Eropa, Amerika Utara, dan Selatan. ${ }^{1}$ Bakteri EHEC memproduksi Shiga-like toxin yang memiliki struktur subunit $\mathrm{AB}_{5}$, terdiri dari satu subunit $A$ yang aktif dan terhubung dengan subunit $B$ pentameric yang bertanggung jawab mengikat toksin dengan reseptor glikolipid pada permukaan sel target. Selain itu Shiga-like toxin bertindak dalam mengeluarkan sinyal transduksi sel dan modulasi sistem imun yang menyebabkan keluarnya sitokin proinflamasi dan apoptosis sel. Kemampuan lainnya dari EHEC adalah melekat pada sel epitel yang menyebabkan lesi seperti pada EPEC yaitu lesi A/E. ${ }^{6,7}$

Penyebaran enteroinvasive E. coli (EIEC) melalui makanan yang tercemar secara sporadis. ${ }^{1}$ Bakteri EIEC melekat pada mukosa kolon dan menginvasi sel secara endositosis melalui sel $\mathrm{M}$, setelah masuk ke lamina, bakteri akan difagosit oleh makrofag dan sel dendritik. Ini merupakan tahap awal respon inflamasi dari invasi bakteri. Bakteri ini bisa menyelamatkan diri dari makrofag dan sel dendritik lalu kembali melakukan invasi pada sel enterosit dan melakukan replikasi di sitoplasma. Bakteri EIEC memicu produksi IL-10, IL-12, dan TNF- $\alpha$ menyebabkan kerusakan lebih luas lagi. ${ }^{7}$
Enteroaggregative E. coli (EAEC) adalah jenis $E$. coli terbanyak kedua yang menyebabkan traveler's diarrhea setelah ETEC. Anak berisiko tinggi terkena traveler's diarrhea, dan bisa menyebabkan diare berat. EAEC sering menyebabkan diare persisten, dengan karakteristik diare cair, sering disertai lendir, dengan atau tanpa darah, nyeri perut, muntah, dan demam ringan. ${ }^{6,7}$ Patogenesis bakteri ini belum cukup dipahami, namun kolonisasi di mukosa usus, formasi biofilm mukoid, beberapa toksin dan sitotoksin, serta inflamasi mukosa menjadi hal utama dalam patogenesis EAEC. ${ }^{6}$

\subsection{Shigella spp.}

Shigella menyebabkan 10-15\% kasus diare akut pada anak di bawah 5 tahun dan menjadi penyebab tersering diare berdarah pada anak. Hanya dibutuhkan 10 hingga 100 mikroorganisme untuk menyebabkan sakit, dengan cara penularan kontak manusia ke manusia melalui fekal-oral., ${ }^{1,5}$

Shigella menginvasi dan bermultiplikasi di sel epitel kolon, menyebabkan kematian sel dan ulkus mukosa. ${ }^{1,10}$ Faktor virulensi Shigella adalah antigen lipopolysaccharide cell-wall, antigen yang digunakan untuk invasi sel; toksin Shiga yang memiliki sifat sitotoksik, dan neurotoksik. ${ }^{1} \mathrm{Di}$ kolon, Shigella merangsang makrofag dan apoptosis sel, hal ini menyebabkan pelepasan sitokin inflamasi IL-1 dan IL-8 sehingga terjadi inflamasi kolon. Shigella keluar dari makrofag setelah terjadi apoptosis dan inflamasi, lalu menginvasi epitel lebih dalam lagi. Peristiwa ini akan mengaktivasi faktor nuklear (kappa B) yang memproduksi IL-8 yang menstimulasi perekrutan netrofil yang menyebabkan kolon semakin inflamasi dan kerusakan epitel semakin luas. Hal ini yang menyebabkan gangguan absorbsi nutrisi dan gejala diare. ${ }^{11}$

Infeksi Shigella menyebabkan demam, diare cair, kram perut, dan tenesmus. ${ }^{5,11}$ Karakteristik fesesnya adalah berdarah, berlendir, dan ditemukan banyak leukosit. ${ }^{5}$ Infeksi biasanya dapat sembuh sendiri, gejala akan membaik dalam waktu 48-72 jam setelah gejala pertama timbul. ${ }^{5}$ Antibiotik diberikan hanya pada anak yang menderita infeksi berat, dengan lini pertama adalah azithromisin yang diberikan selama 5 hari. ${ }^{3,5,11}$

\subsection{Salmonella spp. (non typhoid)}

Target utama Salmonella adalah ileum dan sedikit bagian kolon. ${ }^{1,10}$ Salmonella menghasilkan enterotoksin dan memiliki membran lipopolisakarida yang mengandung antigen Vi. Enterotoksin akan menyebabkan reaksi inflamasi 
sehingga menimbulkan peningkatan sekresi cairan pada usus yang menyebabkan gejala diare. ${ }^{10}$

Gejala yang sering timbul adalah diare tidak berdarah atau berdarah yang disertai dengan nausea, kram perut, dan demam. ${ }^{1,9}$ Diagnosis pasti dilakukan dengan kultur feses. ${ }^{5}$ Bakteremia bisa terjadi dan dapat menyebabkan infeksi ekstraintestinal seperti pada tulang dan meningen, hal ini sering timbul pada anak usia di bawah 3 tahun. ${ }^{1,5}$

Terapi antibiotik disarankan digunakan pada anak dengan risiko tinggi seperti bayi dan anak usia di bawah 3 bulan, anak dengan imunodefisiensi, sedang menjalani terapi kortikosteroid atau imunosupresi, asplenia anatomis atau fungsional. ${ }^{3}$ Antibiotik yang dianjurkan adalah ampisilin/amoksisilin, trimetoprimsulfametoksazol, dan makrolida yang diberikan selama 5-7 hari. ${ }^{1,5}$ Flurokuinolon tidak boleh diberikan pada anak kurang dari 18 tahun karena menyebabkan penutupan metafisis tulang sehingga anak tidak bisa mencapai tinggi maksimalnya. Silakan mencari referensinya atau hapus saja keterangan saya ini.

\subsection{Vibrio cholerae}

Kolera banyak ditemukan di negara Afrika, Asia, dan Amerika Latin. Epidemi biasa timbul pada saat musim panas dan lembab. Prevalensi terbanyak pada anak usia 2-9 tahun, dan gejala yang timbul biasanya berat. Penularan terjadi secara fekal-oral. ${ }^{1,12}$

Vibrio cholerae yang tertelan akan dibunuh sebagian oleh asam lambung, sebagian yang masih bertahan hidup masuk ke usus halus, melakukan kolonisasi pada mukosa usus halus dan mengeluarkan toksin kolera. ${ }^{1,12}$ Toksin kolera adalah protein enterotoksin yang mengandung satu subunit A yang berkerja secara enzimatik untuk mengaktivasi adenil siklase dan meningkatkan cAMP intraselular dan lima subunit B yang berikatan dengan ganglioside $\mathrm{GM}_{1}$ pada sel eukariot. Subunit A merupakan toksin yang menyebabkan gejala diare sekretorik. ${ }^{12,13}$

Gejala khas pada anak yang terinfeksi adalah feses yang sangat cair, hingga 1 liter per jam, tidak berwarna, dan berlendir yang sering disebut sebagai "rice-watery" stools. ${ }^{9,12}$ Gejala lainnya adalah muntah, serta tidak disertai oleh nyeri perut dan tenesmus. ${ }^{12}$

Terapi utama pada kolera adalah terapi rehidrasi, karena banyaknya cairan yang keluar, diperkirakan jumlah cairan yang keluar lebih dari $20 \mathrm{ml} / \mathrm{kg} / \mathrm{jam}$. Rehidrasi dilakukan dengan memberikan cairan rehidrasi oral atau melalui intravena. ${ }^{12}$ Antibiotik diberikan setelah terapi rehidrasi dilakukan, antibiotik pilihan adalah tetrasiklin, azithromisin, dan golongan makrolid. ${ }^{14}$

\subsection{Clostridium difficile}

Secara historis, infeksi $C$. difficile terjadi pada populasi yang memiliki risiko tinggi, dan anak yang sedang dalam terapi pemberian antibiotik. ${ }^{1,5}$ Namun saat ini insidensi infeksi $C$. difficile semakin meningkat di kelompok komunitas biasa. ${ }^{1}$ Prevalensi diare yang disebabkan oleh $C$. difficile meningkat pada anak baik yang sedang dirawat di rumah sakit maupun yang sedang tidak dirawat. ${ }^{1,5}$

Penggunaan antibiotik dan proton pump inhibitor dapat mengganggu keseimbangan flora normal usus besar, sehingga kuman komensal banyak yang mati dan menyebabkan $C$. difficile memiliki kesempatan untuk menimbulkan infeksi. ${ }^{15,16}$

Gejala utama infeksi $C$. difficile adalah diare ringan hingga sedang dan kolitis fulminan yang disebabkan oleh clostridial glycosylation exotoxins, toksin A (TcdA) yang merupakan enterotoksin dan toksin B (TcdB) yang merupakan sitotoksin. ${ }^{15,16}$ Toksin A menyebabkan peningkatan permeabilitas usus dan sekresi cairan. Toksin B menyebabkan reaksi inflamasi kolon. ${ }^{16}$ Kedua toksin ini menyebabkan kerusakan kolonosit, dan merusak intercellular tight junction. Proses ini menyebabkan diare sekretorik dan respon inflamasi dengan kematian sel..$^{15,16}$

Terapi yang direkomendasikan adalah memberhentikan pemberian antibiotik sebelumnya, dan berikan metronidazole selama 10 hingga 14 hari. ${ }^{1,5,16}$ Infeksi $C$. difficile berulang dapat terjadi, pemberian metronidazole ulangan menjadi rekomendasi, bila terus berulang metronidazole dapat diganti dengan pemberian vankomisin. $^{1,5,16}$ Pemberian probiotik dapat membantu pemulihan kembali homeostastis mikrobiota usus, namun masih diperlukan penelitian lebih lanjut lagi mengenai efektivitasnya terhadap diare yang disebabkan oleh pemberian antibiotik dan C. difficile. ${ }^{16,17}$

\section{Diare Akut karena Parasit}

\subsection{Giardia lamblia}

Giardia lamblia mengenai anak pada usia 1-5 tahun dan merupakan penyebab tersering infeksi saluran cerna yang disebabkan oleh parasit. Penyebaran terjadi melalui makanan dan air yang terkontaminasi atau secara fekal-oral. . $^{1,18}$

Siklus hidup G. lamblia terdiri dari bentuk trofozoit dan kista. Bentuk trofozoit tidak bisa hidup di luar tubuh manusia, sedangkan kista 
merupakan bentuk infektif $G$. lamblia, bisa bertahan hidup selama sebulan di air atau tanah. ${ }^{18}$

Mekanisme terjadinya diare pada infeksi $G$. lamblia masih belum jelas. Pada gambaran mikroskopik tampak pemendekan dari epitel dan vili usus. ${ }^{1,10,18}$ Pemendekan ini dipicu oleh aktivasi sel $\mathrm{T}$ limfosit yang diikuti reorganisasi dari F-aktin dan ZO-1 di enterosit melalui fosforilasi MLC. ${ }^{18,19}$ Hilangnya permukaan epitel usus menyebabkan penurunan aktivitas disakaridase yang menyebabkan gangguan absorbsi glukosa dan $\mathrm{Na}^{+}{ }^{18,19}$

Giardia menyebabkan diare akut atau persisten, terkadang terjadi malabsorbsi sehingga feses tampak berminyak, nyeri perut, dan kembung. ${ }^{1,18}$ Giardiasis pada anak gizi cukup akan sembuh dengan sendirinya setelah 3-6 minggu, namun pada beberapa kasus menjadi kronis karena ekskresi parasit yang berlangsung lama dan dapat menyebabkan reinfeksi. ${ }^{18}$

Diagnosis giardiasis ditegakkan dengan menemukan trofozoit dalam pemeriksaan tinja encer dan bentuk kista dalam tinja padat. ${ }^{18}$

Terapi giardiasis menggunakan metronidazole dengan dosis 5-7,5 $\mathrm{mg} / \mathrm{kg}$ berat badan diberikan 3 kali sehari selama 7 hari atau $30 \mathrm{mg} / \mathrm{kg}$ berat badan dosis sekali sehari selama 3 hari. ${ }^{18}$

\subsection{Entamoeba histolytica}

Entamoeba histolytica ditemukan hampir di seluruh dunia terutama di negara berkembang. ${ }^{1,10,18}$ Angka mortalitas akibat infeksi E. histolytica diperkirakan 75.000 per tahun. Infeksi $E$. histolytica dapat melalui makanan dan air serta melalui kontak manusia ke manusia. ${ }^{18}$

Pada siklus hidup E. histolytica mempunyai 3 stadium, yaitu bentuk histolitika, minuta, dan kista. ${ }^{18}$ Stadium histolitika merupakan bentuk patogen dan dapat hidup di jaringan hati, paru, usus besar, kulit, otak, dan vagina. Minuta adalah bentuk pokok. Histolitika dan minuta adalah bentuk trofozoit. Kista terbentuk di rongga usus besar dan dalam tinja, merupakan bentuk infektif. Kista memiliki dinding sehingga dapat bertahan hidup di luar tubuh manusia. ${ }^{18}$

Kista matang yang tertelan oleh manusia akan mencapai lambung, lalu masuk ke rongga usus halus mengalami eksitasi dan keluar dalam bentuk minuta yang masuk ke rongga usus besar. ${ }^{18}$ Minuta berubah menjadi bentuk histolitika yang patogen dan melekat di mukosa dan epitel usus besar dengan bantuan galactose- $N$-acetyl-[D]galactosamine-inhibitable surface lectin. ${ }^{10,18}$ Lectin berperan dalam proses sinyal sitolisis, menghambat deposisi dari komplemen membran dan membantu parasit melekat di proteoglikan usus. ${ }^{10}$

Bentuk histolitika dapat mengeluarkan enzim sistein proteinase yang menyebabkan kerusakan jaringan disebut histolisin. ${ }^{10,18,19}$ Dengan bantuan histolisin, bentuk histolitika akan masuk ke submukosa. Kombinasi penetrasi parasit dan inflamasi menyebabkan ulkus pada epitel sehingga fungsi absorbsi dan pelindung dari usus menjadi berkurang. ${ }^{18,19}$ Dengan bantuan peristalsis usus, bentuk histolitika dikeluarkan bersama isi ulkus ke rongga usus kemudian menyerang lagi mukosa usus yang sehat atau dikeluarkan bersama tinja. ${ }^{18}$

Sekitar $90 \%$ infeksi E. histolytica tidak menimbulkan gejala. ${ }^{1,19}$ Anak dengan E. histolytica dapat mengalami nyeri abdomen, diare inflamasi, anoreksia, dan malaise. Diare biasanya mengandung darah dan mukus yang disertai tenesmus. ${ }^{18}$ Diagnosis ditegakkan dengan ditemukan trofozoit atau kista pada sediaan tinja. ${ }^{1,18}$ Tinja harus diperiksa dalam 1 jam pertama dan dalam suhu kamar karena trofozoit setelah 1 jam akan lisis. ${ }^{18}$

Terapi E. histolytica dengan metronidazole 50 $\mathrm{mg} / \mathrm{kg}$ per hari selama 10 hari diikuti diloxanide furoate $20 \mathrm{mg} / \mathrm{kg}$ berat badan per hari selama 10 hari. $^{18}$

\section{Terapi}

\section{Terapi Cairan Rehidrasi Oral (CRO)}

Banyak kematian pada diare akut disebabkan oleh dehidrasi. ${ }^{1}$ Hal ini cukup disayangkan karena dehidrasi pada diare akut apapun penyebab, jenis, dan usia penderitanya, kecuali diare dengan dehidrasi berat, dapat diterapi dengan pemberian CRO. Oleh karena itu, hal yang pertama kali diperiksa pada anak dengan diare akut adalah status hidrasi. Jika status hidrasi sudah ditentukan, berikan terapi cairan untuk mengembalikan keadaan dehidrasi anak. Cairan rehidrasi oral untuk anak-anak yang masih bisa minum. Jika anak dalam keadaan lemah dan tidak memungkinkan untuk minum, bisa diberikan cairan infus. ${ }^{1}$

Setelah 20 tahun penelitian, cairan rehidrasi oral WHO mengalami perubahan. Saat ini WHO dan UNICEF menganjurkan CRO yang rendah osmolaritasnya. Terapi CRO dengan osmolaritas rendah mengurangi insidensi muntah sebesar $30 \%$ dan volume feses sebesar $20 \%$. Selain itu akan mengurangi kebutuhan penggunaan terapi cairan infus sebesar 33\%., ${ }^{1,20}$ Terapi CRO dengan osmolaritas rendah ini mengandung $75 \mathrm{mEq} / \mathrm{l}$ 
sodium dan $75 \mathrm{mmol} / \mathrm{l}$ glukosa, dan total osmolaritas $245 \mathrm{mOsm} / \mathrm{l}^{1,21,22}$

\section{Zink}

Diare menyebabkan defisiensi zink, yang menyebabkan perjalanan penyakit diare akut semakin berat dan lama. ${ }^{21}$ Diperkirakan bahwa kekurangan zink berperan dalam 176.000 kematian terkait diare pada anak di bawah 5 tahun. ${ }^{22}$ WHOUNICEF pada tahun 2004 merekomendasikan suplementasi zink sebagai terapi tambahan dalam terapi diare akut. Pemberian zink selama 10-14 hari walaupun diare sudah membaik dengan dosis 20 mg untuk anak usia lebih dari 6 bulan dan $10 \mathrm{mg}$ untuk anak kurang dari 6 bulan sebagai terapi diare akut. ${ }^{21-23}$ Zink terbukti efektif dalam mengurangi durasi dan frekuensi diare akut serta mengurangi insidensi diare akut dua hingga tiga bulan ke depan. ${ }^{21-24}$

Mekanisme pemberian zink pada diare akut adalah mengatur transportasi dan absorbsi cairan dan elektrolit di usus, menjaga integritas dan regenerasi mukosa usus, berperan penting dalam imunitas, membunuh patogen dengan lebih baik, memodifikasi ekspresi gen yang mengkode beberapa enzim yang bergantung pada zink seperti metalloprotease, dan sitokin. ${ }^{23,24}$

\section{Probiotik}

Probiotik adalah mikroorganisme hidup yang bila dikonsumsi dalam jumlah yang adekuat akan memberikan dampak menguntungkan pada kesehatan penjamu. Mekanisme kerja probiotik adalah berkompetisi untuk berikatan pada enterosit usus, sehingga enterosit yang sudah jenuh tidak dapat lagi berikatan dengan bakteri lain. ${ }^{5,25}$ Probiotik juga berperan dalam pada imunitas nonspesifik (produksi musin, sel natural killer (NK), makrofag, dan fagositosis) dan spesifik (IL-2, IL6 , TNF- $\alpha$, dan kadar sIgA). ${ }^{25}$ Probiotik yang sering digunakan pada diare akut adalah Lactobacillus reuteri, Lactobacillus acidophilus, Lactobacillus rhamnosus GG, Streptococcus thremophilus dan Bifidobacterium lactis $\mathrm{Bb} 12 .{ }^{25,26}$

Penggunaan probiotik pada anak dengan diare akut dapat mengurangi durasi, frekuensi dan tingkat keparahan diare. ${ }^{25,26}$ Probiotik efektif diberikan sejak gejala awal timbul terutama pada diare yang disebabkan oleh rotavirus. ${ }^{5,27}$

\section{Nutrisi}

ASI memiliki kandungan antimikroba dan kandungan nutrisi yang diperlukan anak yang mengalami diare akut, sehingga harus diberikan parda anak yang mengalami diare akut karena infeksi. ASI bisa segera diberikan walaupun anak sedang mengalami diare. Pemberian ASI terbukti dapat mengurangi durasi dan frekuensi diare akut. ${ }^{1,5,28}$

Pada anak yang tidak mendapatkan ASI, pemberian susu formula yang biasa dikonsumsi bisa diberikan setelah status hidrasi diperbaiki. ${ }^{1}$ Pengenceran susu atau penggantian susu formula menjadi susu formula bebas laktosa tidak perlu dilakukan, kecuali pada anak yang mengalami diare dengan dehidrasi berat. ${ }^{1,5}$

\section{Penutup}

Pengetahuan mengenai diare yang disebabkan oleh infeksi terus berkembang. Kemajuan teknologi memberikan pemahaman yang lebih baik tentang mekanisme yang menyebabkan diare disebabkan oleh infeksi. Diperlukan pertimbangan yang matang dalam penggunaan antibiotik untuk mencegah peningkatan resistensi antibiotik. Pemberian CRO dengan osmolaritas rendah efektif dalam mengurangi durasi dan frekuensi diare akut dengan dehidrasi ringan-sedang dan mengurangi tingkat kematian yang disebabkan oleh diare akut.

\section{Daftar Pustaka}

1. World Health Organization (WHO). Treatment of diarrhoea: a manual for physicians and other senior health workers. Switzerland; 2005. [cited 2021 May 20]. Available from: https://apps.who.int/iris/handle/10665/43209

2. Vu Nguyen T, Le Van P, Le Huy C, Nguyen Gia K, Weintraub A. Etiology and epidemiology of diarrhea in children in Hanoi, Vietnam. Int J Infect Dis. 2006;10(4):298-308.

3. Guarino A, Ashkenazi S, Gendrel D, Lo Vecchio A, Shamir R, Szajewska H. European society for pediatric gastroenterology, hepatology, and nutrition/european society for pediatric infectious diseases evidence-based guidelines for the management of acute gastroenteritis in children in Europe: Update 2014. JPGN. 2014;59(1):132-52.

4. Kang G. Viral diarrhea. Int Encycl Public Heal. 2017;7:360-7.

5. Cajacob NJ, Cohen MB. Update on diarrhea. Pediatr Rev. 2016;37(8):313-22. 
6. Jafari A, Aslani M, Bouzari S. Escherichia coli: a brief review of diarrheagenic pathotypes and their role in diarrheal diseases in Iran. Iran J Microbiol. 2012;4(3):102-17.

7. Gomes TAT, Elias WP, Scaletsky ICA, Guth BEC, Rodrigues JF, Piazza RMF, et al. Diarrheagenic Escherichia coli. Brazilian J Microbiol. 2016;47S:3-30.

8. Zhou Y, Zhu X, Hou H, Lu Y, Yu J, Mao L, et al. Characteristics of diarrheagenic Escherichia coli among children under 5 years of age with acute diarrhea: a hospital based study. BMC Infect Dis. 2018;18:63.

9. World Gastroenterology Organisation (WGO). Acute diarrhea in adults and children: a global perspective. World Gastroenterology Organisation Global Guidelines. Milwaukee; 2012.

10. Navaneethan U, Giannella RA. Mechanisms of infectious diarrhea. Nat Clin Pract Gastroenterol Hepatol. 2008;5(11):637-47.

11. Aslam A, Okafor CN. Shigella ( Shigellosis). [Updated 2019 Dec 14]. In: StatPearls [Internet]. Treasure Island (FL): StatPearls Publishing; 2020. [cited 2021 May 20]. Available from: https://www.ncbi.nlm.nih.gov/books/NBK482 $337 /$

12. Harris JB, LaRocque RC, Qadri F, Ryan ET, Calderwood SB. Cholera. Lancet. 2012;379(9835):2466-76.

13. Satitsri S, Pongkorpsakol P, Srimanote P, Chatsudthipong V. Pathophysiological mechanisms of diarrhea caused by the Vibrio cholerae $\mathrm{O} 1 \mathrm{El}$ Tor variant : an in vivo study in mice. Virulence. 2016;7(7):789-805.

14. Leibovici-Weissman Y, Neuberger A, Bitterman R, Sinclair D, Salam MA, Paul M. Antimicrobial drugs for treating cholera ( Review ). Cochrane Database Syst Rev. 2014;2014(6):CD008625.

15. Mada P, Alam M. Clostridium difficile. [Updated 2020 Jun 26]. In: StatPearls [Internet]. Treasure Island (FL): StatPearls Publishing; 2020. [cited 2021 May 20].
Available from: https://www.ncbi.nlm.nih.gov/books/NBK431 054/

16. Ofosu A. Clostridium difficile infection: a review of current and emerging therapies. Ann Gastroenterol. 2016;29(2):147-54.

17. Mullish BH, Williams HRT. Clostridium difficile infection and antibiotic-associated diarrhoea. Clin Med J R Coll Physicians London. 2018;18(3):237-41.

18. Herbowo, Firmansyah A. Diare akibat infeksi parasit. Sari Pediatr. 2003;4(4):198-203.

19. Hodges K, Gill R. Infectious diarrhea: cellular and molecular mechanisms. Gut Microbes. 2010;1(1):4-21.

20. Sentongo TA. The use of oral rehydration solutions in children and adults. Curr Gastroenterol Rep. 2004;6(4):307-13.

21. Suh JS, Hahn WH, Cho BS. Recent advances of oral rehydration therapy (ORT). Electrolyte Blood Press. 2010;8(2):82-6.

22. Dickinson B, Surawicz CM. Infectious Diarrhea: An Overview. Curr Gastroenterol Rep. 2014;16(8):399-404.

23. Bajait C, Thawani V. Role of zinc in pediatric diarrhea. Indian J Pharmacol. 2011;43(3):232-5.

24. Berni Canani R, Buccigrossi V, Passariello A. Mechanisms of action of zinc in acute diarrhea. Curr Opin Gastroenterol. 2011;27(1):8-12.

25. Shinta K, Hartantyo, Wijayahadi N. Pengaruh probiotik pada diare akut: penelitian dengan 3 preparat probiotik. Sari Pediatr. 2011;13(2):89-95.

26. Guandalini S. Probiotics for prevention and treatment of diarrhea. J Clin Gastroenterol. 2011;45:S149-53.

27. de Vrese M, Marteau PR. Probiotics and Prebiotics: Effects on Diarrhea. J Nutr. 2007;137(3 Suppl 2):803S-811S.

28. Casburn-Jones AC, Farthing MJG. Management of infectious diarrhoea. Gut. 2004;53(2):296-305. 